\title{
The RELATIVE IMPORTANCE OF FinANCIAL RATIOS IN Creating Shareholders' Wealth
}

\author{
Merwe Oberholzer \\ School of Accounting Sciences, North West University, Potchefstoom
}

Accepted: July 2012

\begin{abstract}
The purpose of the study is firstly to use Data Envelopment Analysis (DEA) to aggregate the overall performance (technical efficiency) of firms to convert scarce resources into outputs that create wealth for shareholders, and secondly, to determine the degree to which this mentioned performance is reflected in a number of profitability and market value ratios. Annual financial statement data were used for 55 manufacturing companies listed on the JSE Limited over a five-year period in a cross-sectional analysis. The study found that return on equity has the most significant relationship with technical efficiency, followed by return on assets. The market value ratios price/earnings and dividend yield have no significant relationship with technical efficiency. The value of this study is that it is the first of its kind where technical efficiency, which aggregated operating, profitability and marketability efficiencies, is used to determine the relative importance of not only the readily available profitability ratios, but also market value ratios.
\end{abstract}

Key words: Data Envelopment Analysis, input-oriented, market value ratios, profitability ratios, technical efficiency, variable returns to scale

JEL: C140, D460, G110

1

\section{Background}

This article deals with the relative importance of different financial ratios, in the context where markets are associated with cycles of bubbles and crashes. A bubble is caused by the deviation between a share's overpriced market value and its fundamental (intrinsic) value, which is followed by a crash to correct the market in this systematic over-pricing (Cox \& Hobson, 2005:478). The drivers of fundamental value are often difficult to observe (Hendershott, Hendershott \& Ward, 2003:993), therefore, it is difficult to detect a bubble (Fisher \& Statman, 2002:56). Furthermore, bubbles come into existence as part of the naturally economic cycle or as a result of investor exuberance (Girdzijauskas, Štreimikienè, Čepinskis \& Moskaliova, 2009:268) incited by a belief in the greater fool theory ${ }^{1}$ (Posen, 2006:113).

However, Warren Buffet ${ }^{2}$ does not think in terms of cycles with bubbles and crashes. Market volatility will always exist and therefore he is not concerned about it. $\mathrm{He}$ is much more concerned about the overall potential of a firm, with the emphasis on longterm ownership in a company which is very capable of generating earnings, rather than share value growth (Schroeder, 2008; Investopedia, 2009). The rationale is that if earnings are good, market value will take care of itself. This study is concerned with measuring the overall performance of a firm and to determine how this is reflected in a number of readily available financial ratios.

\section{2}

\section{Statement of the problem}

The bottom line of any firm is to create shareholders' wealth. There are many valuebased measurements that give substance to this performance of creating shareholders' wealth, for example economic value added (EVA), market value added (MVA) and shareholder value added (SVA). MVA, which indicates the growth (or decline) in market values, is the difference between the market share price and its book value (Stewart, 1999:184). The link between MVA and EVA is that MVA is the present value of future EVA values (Baum, 
Saver \& Strickland, 2004:82; Stewart, 1999: 153). SVA is the corporate value less the market value of debt (Rappaport, 1986). A problem is that value-based measurements, such as the above-mentioned, are not readily available and complex to measure (Keys, Azamhuzjaev \& MacKey, 2001:69) and they do not directly measure the growth and dividend components (Stewart, 1999).

Financial ratio analysis, on the other hand, is easy to calculate and also readily available in sources such as financial databases, companies' financial reports and market reports. In this study, financial ratios were investigated, which firstly included five market-based measures, i.e. market value ratios, which are one of three firm valuation methods ${ }^{3}$ (Park \& Lee, 2003). The first market value ratio is the price/earnings (PE) ratio, which is an indication of how much investors would be willing to pay per Rand of profit (Fairfield \& Harris, 1993:591). The price/book value $(\mathrm{PB})$ ratio is a market value ratio that provides an indication of expectations of future performance by relating the market price of a share to the book value of the share (Dunis \& Reilly, 2004:231). The McGregor database also uses a variation of the price/book value ratio, namely the price/net asset value ratio $^{4}$ (PNAV). The value of any organisation is the present value of the future free cash flows and therefore the price/cash flow ratio (PCF) is useful, especially where the price of a share is more related to cash flow than net income (Park \& Lee, 2003:335). Finally, there is the dividend yield method, which is an indication of the dividend yield (DY) relative to the share price (Dunis \& Reilly, 2004:231). Note that the share price is a common component in all five abovementioned equations.

Secondly, three profitability ratios, i.e. accounting-based measures, were used. Profitability, which is the stepping-stone in creating shareholders' value and paying dividends, gets substance in ratios, for example the ratios included in the Du Pont formula that have the strength that they aggregate the firm's performance in three broad categories, namely income, investments and capital structure (Correia, Flynn, Uliana \& Wormald, 2007:520). This analysis indicates how the net profit margin (PM) and asset turnover affect return on assets (ROA), and how ROA and leverage affect return on equity (ROE) (Asaftei, 2008:2337). This study will also include the above-mentioned three profitability measures.

A weakness of financial ratios is that the literature cannot agree upon the relative importance of the different ratios, and it is only appropriate if firms focus on a single input or produce a single output (Chen, 2002:201). Other weaknesses are their lack of objectivity and the lack of a suitable benchmark to compare the ratios against (Hassan Al-Tamimi \& Lootah, 2007:334). Furthermore, no single financial ratio provides an adequate indication of an organisation's performance (Halkos \& Salamouris, 2004:207-208).

What is needed is a measurement tool that can aggregate all inputs (for example, several scarce resources) and outputs (for example, the market value growth and dividend components that are not measured by the value-based techniques) in a single performance measurement. The two most widely used quantitative techniques for measuring relative productivity (or relative efficiency) are Stochastic Frontier Analysis (SFA) and Data Envelopment Analysis (DEA) (Coelli, Rao, O'Donnell \& Battese, 2005:6). DEA is used in this study as an efficiency measurement because it lends itself more easily to the analysis where multiple outputs are used.

The quest for value that benefits the firm and society is the result of directing 'scarce resources to their most promising uses and most productive users' (Stewart, 1999:1). Thus, the performance of any business is measured in terms of how scarce resources are used as an input to obtain the maximum output. DEA can be helpful in this regard, to aggregate firm performance into a single measurement (Avkiran, 1999:206).

Since financial ratios are readily available (but with the weakness that individually they cannot measure Warren Buffet's idea, i.e. the degree to which the overall potential of a firm is achieved) the research question of the study is as follows: Which readily available ratios can help the investor not to buy overvalued/ questionable shares and become trapped as the greater fool? Thus, the core of the study is that it will investigate what the relative importance of financial ratios (market value and profitability ratios) is to reflect a firm's overall performance, 
measured by the technical efficiency (TE) of using scarce resources to create shareholders' wealth.

Therefore, the purpose of the study is twofold, namely firstly to use DEA to aggregate the performance (efficiency) of firms to convert scarce resources into outputs that create shareholders' wealth in a single measurement, and secondly, to determine the degree to which this mentioned performance (efficiency) is reflected in a number of profitability and market value ratios.

The study used DEA efficiency estimates as a measurement superior to financial ratios and therefore as a basis to determine the importance of the different market value ratios and profitability ratios, which are presented by the McGregor database. Section 3 is the literature review and an indication of this paper's contribution, followed by the hypothesis (4) of the study. Sections 5, 6 and 7 explain DEA, the DEA model, data sources and the methodology respectively. The findings of the empirical investigation are shown in Section 8, and the study is concluded in Section 9.

\section{3}

\section{Literature review and contribution of the paper}

Many studies have used market value ratios as independent variables of performance. For example, Ramcharran and Kim (2008) used price/book value along with price earnings to predict market capitalisation values. While Capaul, Rowley and Sharpe (1993) used only price/book value, Dunis and Reilly (2004) used it along with price/earnings, price/cash flow, dividend yield and market capitalisation to identify significant differences between the performance of 'value shares' (shares with a low price/book value ratio) and 'growth shares' (shares with a relatively high price/book value ratio). Park and Lee (2003) concluded in their empirical study that price/book value is the most accurate measure and outperformed ratios such as price/sales ratio and price/cash flow ratio in forecasting stock prices. On the other hand, Fairfield and Harris (1993) used price deviations from basic valuation models to test the intrinsic value of the dependent variable price/book value and price/earning anomalies. Ramcharran (2003) used country risk data to also estimate several dependent variables, namely equity returns, dividend yield, price/ earnings and price/book value.

Some previous studies used DEA efficiency estimates and compared them with profitability ratios and other financial ratios, for example Halkos and Salamouris (2004), Oberholzer and Van der Westhuizen (2004), and Yeh (1996), who found that DEA efficiency estimates are tools aimed at compensating for the weaknesses of financial ratios and that they can be used as an alternative, or complement, to financial ratio analysis. Hassan Al-Tamimi and Lootah (2007:333) also found that financial ratios fail to consider multiple outputs that are provided by multiple inputs, and therefore, DEA efficiency estimates are regarded as superior to financial ratios. Chen (2002) solved the issue to some degree, i.e. the financial ratios versus DEA efficiency estimates debate, by using only financial ratios as outputs in his DEA model. None of these above-mentioned studies focused on market value ratios and they all used a single stage process. Seinford and Zhu (1999) developed a more advanced two-stage process where the first stage measures profitability efficiency and the second stage marketability efficiency. The inputs of the first stage are labour and assets, while revenue and profits are the outputs. The outputs of stage one automatically form the inputs for stage two and the outputs of stage two include market values, returns and earnings per share. The problem with this model is that adjustments should be made to reduce the outputs of the first stage in order to increase the efficiency of the second stage. These adjustments result in a situation where it is unknown where the DEA frontier is. Therefore, Chen, Cook and Zhu (2010) developed an approach to deal with it. Since the available software (Zhu, 2004) cannot deal with this issue, a single stage approach was used that included both the profitability and marketability. A multiple inputoutput DEA model can measure company performance much more comprehensively than any financial ratio, which is only a singleinput-single-output measure. These previous studies will serve as a basis to develop a suitable DEA model to estimate the overall performance of companies under review.

However, in spite of a widespread adoption 
of measurements, such as market value ratios as dependent or independent variables and DEA efficiencies versus profitability ratios, there has been no empirical linkage between DEA and profitability ratios and market value ratios. Therefore, this study extends the current literature by using both profitability ratios and market value ratios as independent variables, while DEA efficiency will be the dependent variable to indicate the importance of financial ratios relative to a firm's efficiency of using scarce resources to create shareholders' wealth. Accordingly, this study will investigate 55 companies in three sectors on the JSE Limited over a fiveyear period to determine cross-sectional associations. The results of this study will indicate the relative importance of the different market value ratios and profitability ratios relative to the DEA efficiency. DEA will be used to estimate the annual technical efficiency of each company and Spearman's rank-order correlation analysis will be used to determine the relationship between these efficiency estimates and the different financial ratios.

4

\section{Hypothesis}

DEA is a technique for combining all the input and output data about the firm into a single measure of productive (in this case, technical) efficiency, which lies between zero (meaning the firm is totally inefficient) and one (which signals that the firm is fully efficient). The profitability ratios indicate a firm's profitability relative to sales, assets and equity, respectively. Thus, the higher the ratio, the more profitable the firm is. Market value ratios, such as price/ earnings, price/cash flow, price/book value and price/net asset value, are an indication of what investors think about a firm's past, current and future risks and returns. These risks and returns determine share prices and thus market value (Orlitzky, Schmidt \& Rynes, 2003:407408). Therefore, the higher these ratios, with other things held constant, the higher the prospects and/or the lower the risk. This is in contrast to dividend yield, where a higher ratio indicates lower prospective yield and higher risk (Dunis \& Reilly, 2004:231).

Therefore, the conceptual framework of the study is that there should be a positive relation- ship between the technical efficiency (dependent variable) of a firm and its profit-ability and market value ratios; except for dividend yield, where a negative relationship is expected.

If it is assumed that the more complicated technical efficiency indicates the overall performance of a firm, a high correlation with a specific readily available financial ratio (except dividend yield) will indicate that the ratio also has the ability to indicate the overall performance of a firm. A low or negative correlation between the technical efficiency and a specific ratio will indicate that the ratio does not have the ability to indicate a firm's overall performance, but that it only helps the investor to be trapped as the greater fool, i.e. where low performance firms (shares) are indicated to have high prospective yield and/or low risk.

The conceptual framework will be helpful to test the following null-hypothesis:

$\mathrm{H}_{0}$ : There is no monotone significant relationship between technical efficiency estimates of creating shareholders' wealth and the different financial ratios.

\section{5}

\section{Data Envelopment Analysis (DEA)}

DEA is a non-parametric linear programming technique that measures the relative efficiency of a comparative ratio of outputs to inputs for each decision-making unit (DMU), such as a firm (Avkiran, 1999:206). A firm is efficient 'if it cannot produce more output without a corresponding relative increase in inputs, or if it cannot reduce its inputs without a corresponding relative decrease in outputs' (Thomas $\&$ Tripe, 2007:4). The traditional measurement of efficiency assumes only a single output divided by a single input (Cronjé, 2002:33). The main advantage of using DEA as a relative efficiency measure is that it accommodates multiple inputs, multiple outputs and other factors in a single model (Halkos \& Salamouris, 2004). The main usefulness is its ability to identify inefficient firms, to generate potential improvement for them and indicate efficient firms that should be used as a benchmark by the inefficient ones (Avkiran, 1999:206).

DEA can be used to estimate four main types of efficiency, namely technical, allocative, economic and scale efficiency. In practice, the 
measurement of these efficiencies involves the estimation of production frontiers. DEA effectively estimates the frontier by finding a set of linear segments that envelop the observed data. Technical efficiency is an indication of how well inputs are converted into outputs, while allocative efficiency reflects the ability of a firm to use the inputs in optimal proportions, given their respective prices (Avkiran, 1999: 206-207). A firm is economically efficient if it is both technically and alloca-tively efficient, and a firm is scale efficient if it operates on a scale that maximises productivity (Oberholzer \& Van der Westhuizen, 2009:69). DEA can determine efficiencies from an input-orientated (input minimisation) or output-orientated (output maximisation) point of view (Avkiran, 1999: 211; Oberholzer \& Van der Westhuizen, 2009: 74). Furthermore, analysts choose between using constant return to scale (CRS) or variable return to scale (VRS). The first implies a proportionate rise in outputs when inputs are increased, in other words, a firm's efficiency is not influenced by the scale of operations (Avkiran, 1999:211). 'VRS implies a disproportionate rise or fall in outputs when inputs are increased' (Avkiran, 1999:211), in other words, if a firm grows in size, its efficiency will not stay constant, but it will either rise or fall.

\section{6}

\section{DEA model}

Avkiran (1999:214) gives a guideline as to when inputs and outputs are selected - the outputs should be the key business drivers that are critical to the success of the business, and the inputs should be the resources that lead to the key business drivers. A combination of approaches was used to determine inputs. Assets, and in some cases only tangible assets or fixed assets, were used by Chen (2002), Oberholzer and Van der Westhuizen (2009), and Favero and Papi (1995). Shareholders' equity was used by Stavarek (2002) and Oberholzer and Van der Westhuizen (2009). Expenditure was used by Hassan Al-Tamimi and Lootah (2007). In this study, tangible assets, shareholders' equity at book value and total expenditure were used as the input resources.

Although the Modigliani-Miller theorem states that the value of a company is indepen- dent of reinvestments and dividend pay-outs ${ }^{5}$, this is not true since both components are not free of costs (Paulsen, 2008:2201). The reward that investors get from buying shares in a company is measured by the cash component and the value component, which are the dividend payouts and the growth in the market value of the shares, respectively (Arnott \& Asness, 2003: 70-71; Nel, 2005:5). Growth (change) in market share value cannot be used as an output variable since it may take on a negative value as a result of the volatility in the market (JSE, 2009). The reason is that a DEA model requires positive data (Luo, 2003:631; Zhu, 2004:266). Halme, Joro and Koivu (1998) also confirm that the most widely used models by Charnes, Cooper and Rhodes (1978) and Banker, Charnes and Cooper (1984) require that all the input and output data are strictly positive. Market value of shareholders' equity can be used as an output variable and that will be justified by the fact that its book value is used as an input value. Market value was also used as an output value by Seinford and Zhu (1999) and Chen, et al. (2010). Profit can also be considered as an output value, but the problem is that it also can take on a negative value. Therefore, sales revenue is used as an output value to justify total expenditure as an input.

The following DEA model was specified:

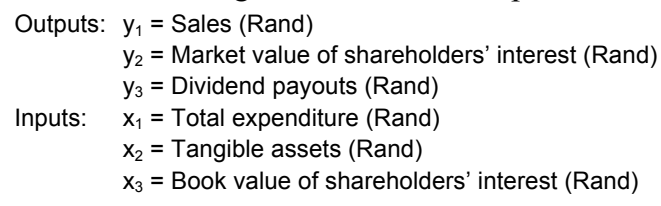

The results of this model will give an aggregated measure of the operating efficiency (since sales is an output that is opposed to the input of scarce resources), profitability efficiency (since sales is an output that is opposed to total expenditure), and marketability efficiency (since the market value of shareholders' interest and dividends as outputs are opposed to the input of the book value of shareholders' interest).

Note that the management of a firm does not have equal control with regard to the efficiency needed to reach the outputs, for example, the management of a firm has much more control with regard to the operating and profitability efficiency than the marketability efficiency. But, this is not the point! This study 
is more concerned with how the technical efficiencies of a firm, and not of management, are related to the financial ratios. Also note that market value is a component in all the market value ratios that will be compared to DEA in the empirical study.

\section{7}

\section{Data sources and methodology}

Companies use different year-end dates and performances are determined relative to these dates. The market volatility influences the market value of shares, therefore share prices of companies with different year-end dates cannot be compared at year-end. Inflation may also influence values such as assets and shareholders' interest if the year-end dates are different. Therefore, only companies that use the same year-end dates will be grouped together.

Since differences can be expected between different sectors, it was decided to only include the following three sectors in the study rather than the whole JSE. The study includes Basic Materials, Industrials and Consumer Goods. The reason for choosing these sectors is that they all have manufacturing of tangible products in common.

In order to reach the first objective of the study, income statement, balance sheet and market data were used in the DEA model to calculate the input-orientated technical efficiency estimates for the selected companies. In total, 22 companies with December and 33 with June as their yearends were included in the study. Companies with other year-ends than these did not provide a large enough sample to be investigated. The annual technical efficiencies for the companies in the two samples (22 and 33) were calculated relative to the other companies in that sample. The sample size of 22 and 33 observations is sufficient, according to Avkiran (1999:207208), who states that it should be three times as large as the sum of the chosen variables, thus $22>3(3+3)$ and $33>3(3+3)$.

Data for the inputs included in the DEA model were taken from the balance sheet, i.e. Rand (book) value of total tangible assets and the Rand (book) value of shareholders' interest, and from the income statement, the Rand value of expenditure was taken. The outputs included were calculated by using the number of shares issued multiplied by the share price at year-end. This was to determine a company's efficiency that is only valid for the last day of its financial year. These efficiency estimates were compared to the financial ratios, also as calculated at the company's financial year-end. Furthermore, the output Rand value of sales and the Rand value of dividend payouts were taken from the income statement.

Data were taken for a five-year period, from 2004 to 2008. A comparison was made over the five-year period between the 55 companies in each year. A five-year period is used to determine whether the results are consistent among the years.

The software package of Zhu (2004) is purpose-built to solve the DEA problem and has been used in this paper to generate estimates of annual input-orientated technical efficiency for each company over a five-year period. The inputorientated approach promotes an emphasis on cutting input expenditure, capital and tangible assets rather than expanding sales, market value of shareholders' equity and dividend payouts. Although all the companies in the sample are involved in manufacturing, the variable return to scale approach was used rather than the constant return to scale approach, because of the divergent operations and sizes of the companies.

In this study, the following DEA formulae were used for an input-orientated model with a variable return to scale approach. This is where the inputs are minimised, while the outputs are kept at their current levels (Zhu, 2004:5-13):

$$
\begin{array}{ll}
\min \theta-\varepsilon\left(\sum_{i=1}^{m} s_{i}^{-}+\sum_{r=1}^{s} s_{r}^{+}\right) & \\
\text {subject to } & i=1,2, \ldots, m ; \\
\sum_{j=1}^{n} \lambda_{j} \chi_{i j}+s_{i}^{-}=\theta \chi_{i o} & r=1,2, \ldots, s ; \\
\sum_{j=1}^{n} \lambda_{j} \gamma_{r i}-s_{r}^{+}=\gamma_{r o} & \\
\sum_{j=1}^{n} \lambda_{j}=1 & j=1,2, \ldots, n .
\end{array}
$$

The input-orientated formula calculates input minimisation (where $\theta$ indicates the efficiency score). Each observation, $D M U_{j}(j=1, \ldots, n)$, uses $m$ inputs $X_{i j}(\mathrm{i}=1,2, \ldots, m)$ to produce $s$ outputs $\mathrm{Y}_{\mathrm{rj}}(r=1,2, \ldots, s)$, and where $D M U_{o}$ represents one of the $n$ DMUs under evaluation, and $X_{i o}$ and $Y_{r o}$ are the $i$ th input and 
$r$ th output for $D M U_{o}$, respectively. In order to consider any slacks, the presence of the nonArchimedean $\varepsilon$ effectively allows the minimisation over $\theta$ to pre-empt the optimisation involving the slacks, $s_{i}{ }^{-}$and $s_{r}{ }^{+}$. [For a more detailed discussion on the DEA methodology, see Cronje (2002), Avkiran (1999), Ray (2004) and Zhu (2004).]

To reach the second objective, market value ratios and profitability ratios were taken from the McGregor database. Although financial models rely heavily on normality of data, Melas and Ruban (2009) proved that financial data are not normally distributed. Since normality is a prerequisite for linear regression analysis (Levine et al. 2008:530), Spearman's correlation was used to determine the degree to which technical efficiency changes if there is a change in the financial ratios. The rank order correlation of Spearman may be used to determine whether there is a monotone dependence between each of the eight independent variables (financial ratios) and the technical efficiency. Rank order correlation is a non-parametric technique for qualifying the relationship between two variables. Non-parametric means that the correlation statistics are not affected by the type of mathematical relationship between variables, unlike the least square regression analysis that requires the relationship to be linear (Vose, 1996:33). The Spearman rank order correlation coefficient is a more general measure of any kind of monotonic relationship between the dependent and independent variables. This measure is based on ranks and therefore not as sensitive to outliers (Millard \& Neerchal, 2001:534). Regression and correlation analysis with one independent variable requires a sample of at least ten observations (Sekaran, 2006:294-297; Hanke, Wichern \& Reitsch, 2001:73). Each sample provides 22 and 33 data-points per year.

Finally, the null-hypothesis is tested by using p-values at one, five and ten per cent significant levels.

8

\section{Empirical results}

The input-orientated technical efficiency of the companies under review was determined, and as a result of space restriction only the results of the 22 companies with a December year-end will be shown, as well as the annual averages of the 33 companies with June year-ends. Table 1 indicates the relative efficiency of how the inputs (scarce resources) are converted to outputs that create shareholders' wealth. Six of the 22 companies (AMS, HVL, GND, ILA, MOB and PMV) were fully efficient during the period 2004 to 2008 . The meaning of these estimates is, for example the first listed company (AFE), that this company has on average a relative efficiency of 92.4 per cent, which indicates that it could reduce the consumption of its inputs by 7.6 per cent without reducing its outputs. The last company listed in the table (TON) is on average the most inefficient with an average estimate of 68.4 per cent. It is also clear that there are variations of the technical efficiency between companies, as well as variations between the annual averages of the two samples. Also remarkable is the fact that the total averages of the two samples over the five-year period are almost the same, namely 91.3 per cent and 91.6 per cent for the December and June yearend companies, respectively.

Table 2 contains the descriptive statistics of the data for the two samples of companies investigated which were also used in Table 3 to determine the relationship between the technical efficiency estimates and the financial ratios of the two samples, respectively.

In Table 2, no adjustments were made for outliers. It is clear that there are differences between the means and the medians (and in some cases huge differences, for example, the dividend yield of the first sample). This is probably the result of some outliers, large variances and a lack of normality of the data. There are also some major differences between the means of the two samples, for example, the dividend yield of the two samples. The latter will not be addressed since the issue is not to compare the means of the two samples, but only to determine independently whether there are differences when the financial ratios are compared to the technical efficiency in each sample. The first issue was expected (see Section 7), therefore Spearman's correlation coefficient is used. 
Table 1

Input-orientated technical efficiency of companies, 2004-2008

\begin{tabular}{|c|c|c|c|c|c|c|}
\hline \multicolumn{7}{|c|}{ December year-end companies $(n=22)$} \\
\hline Company & 2008 & 2007 & 2006 & 2005 & 2004 & Avg. \\
\hline AFE & 0.849 & 0.883 & 0.897 & 0.991 & 1.000 & 0.924 \\
\hline AFX & 0.929 & 0.885 & 0.868 & 0.874 & 1.000 & 0.911 \\
\hline AMS & 1.000 & 1.000 & 1.000 & 1.000 & 1.000 & 1.000 \\
\hline ANG & 1.000 & 0.608 & 0.628 & 0.858 & 1.000 & 0.819 \\
\hline $\mathrm{ACL}$ & 1.000 & 0.920 & 0.832 & 1.000 & 1.000 & 0.950 \\
\hline DTA & 0.971 & 0.548 & 0.514 & 1.000 & 0.822 & 0.771 \\
\hline EXX & 0.764 & 0.973 & 1.000 & 1.000 & 1.000 & 0.947 \\
\hline HVL & 1.000 & 1.000 & 1.000 & 1.000 & 1.000 & 1.000 \\
\hline MRF & 1.000 & 0.811 & 0.475 & 0.695 & 0.887 & 0.773 \\
\hline PAM & 0.784 & 1.000 & 1.000 & 1.000 & 0.382 & 0.833 \\
\hline BSR & 0.964 & 1.000 & 1.000 & 1.000 & 1.000 & 0.993 \\
\hline BEL & 0.835 & 0.924 & 0.908 & 0.870 & 0.868 & 0.881 \\
\hline $\mathrm{CNL}$ & 0.755 & 1.000 & 0.768 & 0.876 & 1.000 & 0.880 \\
\hline GND & 1.000 & 1.000 & 1.000 & 1.000 & 1.000 & 1.000 \\
\hline HWN & 1.000 & 1.000 & 1.000 & 0.869 & 1.000 & 0.974 \\
\hline ILA & 1.000 & 1.000 & 1.000 & 1.000 & 1.000 & 1.000 \\
\hline MMG & 0.934 & 1.000 & 1.000 & 1.000 & 1.000 & 0.987 \\
\hline MOB & 1.000 & 1.000 & 1.000 & 1.000 & 1.000 & 1.000 \\
\hline PMV & 1.000 & 1.000 & 1.000 & 1.000 & 1.000 & 1.000 \\
\hline TRE & 1.000 & 1.000 & 0.528 & 1.000 & 0.957 & 0.897 \\
\hline MTA & 0.834 & 0.872 & 0.841 & 0.773 & 0.952 & 0.855 \\
\hline TON & 0.791 & 0.564 & 0.649 & 0.637 & 0.780 & 0.684 \\
\hline Average & 0.928 & 0.909 & 0.859 & 0.929 & 0.939 & 0.913 \\
\hline \multicolumn{7}{|c|}{ June year-end companies $(n=33$ ) } \\
\hline Company & 2008 & 2007 & 2006 & 2005 & 2004 & Avg. \\
\hline Average & 0.877 & 0.910 & 0.917 & 0.922 & 0.953 & 0.916 \\
\hline
\end{tabular}

Software package used: Zhu (2004)

Table 2

Descriptive statistics of variables: Average 2004-2008

\begin{tabular}{|c|c|c|c|c|c|c|c|c|c|}
\hline \multicolumn{10}{|c|}{ December year-end companies $(n=22)$} \\
\hline & \multirow{2}{*}{$\begin{array}{c}\text { DEA } \\
\text { TE }\end{array}$} & \multicolumn{3}{|c|}{ Profitability ratios } & \multicolumn{5}{|c|}{ Market value ratios } \\
\hline & & PM & ROA & ROE & DY & PE & PB & PNAV & PCF \\
\hline Mean & 0.91 & 10.35 & 17.03 & 13.00 & 9.14 & 7.69 & 2.48 & 2.53 & 6.70 \\
\hline Std error & 0.02 & 2.68 & 2.86 & 8.88 & 2.93 & 3.14 & 0.34 & 0.38 & 1.23 \\
\hline Median & 0.94 & 8.18 & 13.74 & 15.34 & 4.24 & 9.04 & 1.99 & 2.07 & 6.07 \\
\hline Std deviation & 0.09 & 12.56 & 13.40 & 41.63 & 13.74 & 14.72 & 1.57 & 1.77 & 5.78 \\
\hline Variance & 0 & 158 & 180 & 1733 & 189 & 217 & 2.5 & 3.1 & 33.4 \\
\hline Kurtosis & 0.16 & 1.05 & 1.20 & 3.36 & 9.72 & 4.64 & -0.21 & 4.62 & 2.22 \\
\hline Skewness & -0.94 & 0.47 & 0.98 & -1.62 & 2.85 & -0.81 & 0.50 & 1.88 & -0.58 \\
\hline Range & 0.32 & 58.26 & 56.55 & 174.93 & 61.13 & 80.06 & 6.01 & 7.94 & 27.39 \\
\hline Minimum & 0.68 & -16.2 & -3.95 & -99.01 & 0.00 & -35.2 & -0.62 & 0.37 & -9.34 \\
\hline Maximum & 1.00 & 42.11 & 52.61 & 75.92 & 61.13 & 44.87 & 5.39 & 8.31 & 18.05 \\
\hline Confidence & 0.04 & 5.57 & 5.94 & 18.46 & 6.09 & 6.53 & 0.70 & 0.78 & 2.56 \\
\hline \multicolumn{10}{|c|}{ June year-end companies $(n=33)$} \\
\hline & DEA & \multicolumn{3}{|c|}{ Profitability ratios } & \multicolumn{5}{|c|}{ Market value ratios } \\
\hline & TE & PM & ROA & ROE & DY & PE & PB & PNAV & PCF \\
\hline Mean & 0.92 & 4.01 & 12.57 & 13.00 & 2.30 & 13.03 & 2.30 & 2.05 & 4.27 \\
\hline Std error & 0.02 & 3.09 & 2.16 & 6.63 & 0.44 & 2.19 & 0.24 & 0.33 & 3.89 \\
\hline Median & 0.94 & 4.30 & 11.70 & 18.75 & 1.40 & 10.75 & 1.97 & 1.96 & 8.01 \\
\hline Std deviation & 0.10 & 17.74 & 12.38 & 38.08 & 2.53 & 12.57 & 1.39 & 1.88 & 22.35 \\
\hline Variance & 0.01 & 315 & 153 & 1450 & 6.42 & 158.0 & 1.92 & 3.52 & 500 \\
\hline Kurtosis & 4.28 & 9.52 & 1.50 & 19.15 & 0.08 & 3.95 & 5.40 & 8.46 & 9.45 \\
\hline Skewness & -1.90 & -2.40 & -0.37 & -4.10 & 0.97 & 1.79 & 0.14 & -2.19 & -0.65 \\
\hline Range & 0.43 & 102.6 & 60.3 & 220.3 & 9.09 & 59.9 & 8.98 & 11.10 & 159.6 \\
\hline Minimum & 0.57 & -70.4 & -21.5 & -174 & 0.00 & -6.59 & -2.2 & -5.53 & -79.8 \\
\hline Maximum & 1.00 & 32.29 & 38.83 & 46.42 & 9.09 & 53.3 & 6.76 & 5.57 & 79.8 \\
\hline Confidence & 0.03 & 6.29 & 4.39 & 13.50 & 0.90 & 4.46 & 0.49 & 0.67 & 7.93 \\
\hline
\end{tabular}

Software used: Microsoft Excel 
Table 3 indicates Spearman's correlation coefficient between technical efficiency and profitability and market value ratios. To test the null-hypothesis, namely that there is no monotone significant relationship between technical efficiency estimates of creating shareholders' wealth and the different financial ratios, the p-values related to the abovementioned correlation coefficients were also determined. The null-hypothesis is rejected in some cases at a significance level of one, five and ten per cent, where $\rho<\alpha=0.01,0.05$ and 0.10 , respectively (two-tailed). It is also clear, according to both samples, that return on equity has significant positive relationships with technical efficiency for all the years. Sample 2, 2008, indicates a significant level of ten per cent, implying a weak sample evidence, which is not statistically significant and cannot be used to reject $\mathrm{H}_{0}$ in favour of $\mathrm{H}_{1}$. The remaining significance levels are one per cent and five per cent, implying there is overwhelming strong sample evidence and strong sample evidence, respectively, to reject $\mathrm{H}_{0}$ in favour of $\mathrm{H}_{1}$ (Wegner, 2007:266-267). Return on assets has the second highest significant relationships with technical efficiency, where the significance levels are five per cent in five different years for the two samples. The correlation coefficients are only significant in some cases for price/net asset value, price/book value, price/cash flow and profit margin. Both samples also indicate that there is never a significant positive relationship between technical efficiency and price/earnings and dividend yield ratios.

\section{Table 3}

Spearman's rank-order correlation between technical efficiency and profitability and market value ratios

\begin{tabular}{|c|c|c|c|c|c|c|c|c|}
\hline \multicolumn{9}{|c|}{ December year-end companies $(n=22)$} \\
\hline & \multicolumn{3}{|c|}{ Profitability ratios } & \multicolumn{5}{|c|}{ Market value ratios } \\
\hline & PM & ROA & ROE & DY & PE & PB & PNAV & PCF \\
\hline 2008 & 0.313 & $0.486^{\star *}$ & $0.486^{* *}$ & 0.035 & -0.318 & 0.183 & 0.309 & -0.024 \\
\hline 2007 & -0.236 & $0.415^{*}$ & $0.672^{\star * \star}$ & 0.011 & -0.236 & -0.039 & 0.080 & -0.088 \\
\hline 2006 & 0.023 & $0.471^{* *}$ & $0.536^{* *}$ & 0.070 & 0.088 & 0.267 & $0.452^{* *}$ & 0.059 \\
\hline 2005 & $0.396^{*}$ & 0.349 & $0.598^{* * *}$ & 0.057 & -0.132 & 0.014 & 0.062 & $-0.637^{* * *}$ \\
\hline 2004 & $0.473^{*}$ & $0.415^{\star}$ & $0.438^{* *}$ & 0.213 & 0.143 & 0.218 & $0.384^{*}$ & 0.061 \\
\hline Total & 0.112 & $0.413^{*}$ & $0.592^{\star \star \star}$ & 0.005 & -0.160 & 0.238 & $0.378^{*}$ & -0.070 \\
\hline \multicolumn{9}{|c|}{ June year-end companies $(n=33)$} \\
\hline & \multicolumn{3}{|c|}{ Profitability ratios } & \multicolumn{5}{|c|}{ Market value ratios } \\
\hline & PM & ROA & ROE & DY & PE & PB & PNAV & PCF \\
\hline 2008 & 0.113 & $0.441^{* *}$ & $0.382^{*}$ & 0.252 & 0.008 & 0.279 & $0.352^{*}$ & 0.143 \\
\hline 2007 & 0.132 & 0.300 & $0.698^{\star \star \star}$ & 0.212 & 0.132 & $0.383^{*}$ & 0.303 & 0.088 \\
\hline 2006 & 0.034 & $0.501^{\star *}$ & $0.690^{* \star *}$ & 0.297 & -0.216 & 0.033 & 0.159 & -0.301 \\
\hline 2005 & 0.241 & $0.446^{* *}$ & $0.574^{* \star *}$ & 0.152 & -0.096 & 0.236 & 0.198 & -0.035 \\
\hline 2004 & 0.041 & 0.237 & $0.462^{\star \star}$ & -0.239 & -0.120 & 0.318 & 0.333 & -0.163 \\
\hline Total & 0.129 & $0.398^{\star *}$ & $0.758^{* \star *}$ & 0.132 & -0.086 & 0.219 & 0.188 & 0.083 \\
\hline
\end{tabular}

* Significant at 10\% (two-tailed) ** Significant at 5\% (two-tailed)

*** Significant at $1 \%$ (two-tailed)

Software used: Microsoft Excel

\section{9}

\section{Conclusion}

This study investigated the annual performance of two sample groups of 22 and 33 companies listed at the JSE Limited in the Basic Material, Industrial and Consumer Goods sectors from 2004 to 2008. The purpose of the study was firstly to use DEA to aggregate the performance (efficiency) of firms to convert scarce resources into outputs that create shareholders' wealth in a single measurement, and secondly, to determine the degree to which this mentioned performance (efficiency) is reflected in a number of readily available profitability and market value ratios.

The study concludes that the DEA model used is suitable to indicate in a single measurement the relative efficiency of firms to 
convert scare resources (for example, tangible assets, book value of shareholders' interest and payments for resources such as labour, materials, equipment, transport) in sales, market value of shareholders' interest and dividends. Since DEA models require positive data, these selected inputs and outputs are usually positive and will only be negative by exception, for example, a bankrupt firm with higher liabilities than assets will have a negative book value in terms of shareholders' interest. The results of this model also give an aggregated measure of the operating efficiency, profitability efficiency and marketability efficiency. What is also important is that inefficient companies can also be identified and investigated further to detect the reasons for their poor levels of performance. Furthermore, the efficient companies can be used as a benchmark for the inefficient ones. The practical implication of this study is that this model or similar models can be used to determine the overall firms' performance, i.e. the relative efficiency to create shareholders' wealth included a firm's operations, profitability and marketability efficiencies.

The study found, with regard to both samples, that return on equity has the most significant positive relationship with technical efficiency, followed by return on assets. The relationship is only significant for price/net asset value, price/book value, price/cash flow and profit margin ratios for a limited number of years. The market value ratios, that is, price/earnings and dividend yield, have significant relationships with technical efficiency in none of the years. Therefore, the study also concludes that the overall performance of a company, namely to convert scarce resources into shareholders' wealth, can easily be substituted by using the readily available return on equity, and to a lesser extent, return on assets. These two profitability ratios are, in the context of this study, relatively the most important, and outperformed the profit margin ratio and all the market value ratios, even while the DEA model and all the market value ratios have market value as a common component. The practical implication is that return on equity, and to a lesser extent return on assets, is a sensible indication of the overall performance of firms, that is, the relative efficiency with which to create shareholders' wealth.

Some of the remaining ratios, price/book value, its variation price/net asset value, price/cash flow and profit margin provide only a very limited indication of a firm's relative operating, profitability and marketability efficiency. Therefore, they should rather be grouped together with the relatively less important ratios such as price/earnings and dividend yield where no significant relationships were found. With reference to the research question, these market-based ratios should be used by investors only as short-term market indicators as they are excellent aids for speculation purposes, but tell nothing about the overall performance of a firm. Thus, using these ratios will be helpful in being the lucky fool, if you can get rid of the shares before the bubble bursts, to avoid being the greater fool.

The value of this study is that it is the first where the technical efficiency, determined by DEA, which aggregated operating, profitability and marketability efficiencies, is used to determine the relative importance of not only profitability ratios, but also market value ratios. Further research is necessary, since the element of risk is not included in the DEA model. Variations of the DEA model can be used, for example, to include total assets instead of tangible assets as an input, and can be compared to the results of this study. A more advanced DEA model can also be developed for further analysis to determine scale, allocative and economic efficiencies.

\section{Endnotes}

1 The Greater Fool Theory is based on making money through buying probable overvalued or questionable shares and to sell them to someone (the greater fool) who is willing to pay a higher price for them. Unfortunately, sooner or later the bubble will burst and someone will be the owner of shares that are worth much less than they were purchased for (Cox \& Hobson, 2005:477-478; Sanford, 2005:45)

2 Warren Buffet, an American investor, businessman and philanthropist, was, in 2006, ranked as the second richest person in the world. In 2006 he announced that he would donate $85 \%$ of his fortune, worth $\$ 37$ billion, mainly to the Bill and Melinda Gates Foundation (Schroeder, 2008:815-816). 
3 The three different approaches of firm valuation are market value ratios (also known as multiples or relative valuation method), discounted cash flow method and contingent claims valuation method (Park \& Lee, 2003).

4 According to the formula Equity = Assets - Liabilities, the net asset value (NAV), which is Assets - Liabilities, is the same as the book value of equity. However, the McGregor database calculates NAV as Tangible Assets - Current and Longterm Liabilities.

5 In the literature, there are different opinions with regard to the influence of dividend payments (cash component) on market values. The point of view of one theory is that dividends lead to higher market values; a more radical postulates that it reduces value; and the middle-of-the-road theory, based on the work of Miller/Modigliani, is that dividends are irrelevant with regard to market value (Paulson, 2008:2201; Correia et al., 2007:16-4).

\section{References}

ARNOTT, R.D. \& ASNESS, C.S. 2003. Surprise! Higher dividends = higher earnings growth, Financial Analysts Journal, 59(1):70-87.

ASAFTEI, G. 2008. The contribution of product mix versus efficiency and technical efficiency change in US banking, Journal of Banking \& Finance, 32:2336-2345. Available at: www.sciencedirect.com [accessed 2011-11-21].

AVKIRAN, N. 1999. An application reference for data envelopment analysis in branch banking: helping the novice researcher, International Journal of Bank Marketing, 17(5):206-220.

BANKER, R.D., CHARNES, A. \& COOPER, W.W. 1984. Some models for estimating technical and scale efficiencies in data envelopment analysis, Management Science, 30(9):1078-1092.

BAUM, C.L., SAVER, L. \& STRICKLAND, T. 2004. EVA, MVA and compensation: further evidence, American Business Review, 22(2):82-87.

CAPUAL, C., ROWLEY, I. \& SHARPE, W.E. 1993. International value and growth stock return, Financial Analysis Journal, Jan.-Feb.:27-36.

CHARNES, A., COOPER, W.W. \& RHODES, E. 1978. Measuring efficiency of decision-making units, European Journal of Operations Research, 2:429-444.

CHEN, T. 2002. Measuring firm performance with DEA and prior information in Taiwan's banks, Applied Economic Letters, 9(3):201-204.

CHEN, Y., COOK, W.D. \& ZHU, J. 2010. Deriving the DEA frontier for two-stage processes, European Journal of Operating Research, 202(1):138-142.

COELLI, T.J., RAO, D.S.P., O'DONNELL, C.J. \& BATTESE, G.E. 2005. An introduction to efficiency and productivity analysis, New York: Springer:

CORREIA, C., FLYNN, D., ULIANA, E. \& WORMALD, M. 2007. Financial management ( $6^{\text {th }}$ ed.) Cape Town: Juta.

COX, A.M.C. \& HOBSON, D.G. 2005. Local martingales, bubbles and option prices, Finance Stochast, 9:477-492.

CRONJE, J.J.L. 2002. Data envelopment analysis as a measure for technical efficiency measurement in banking - a research framework, Southern African Business Review, 6(2):32-41.

DUNIS, C. \& REILLY, D. 2004. Alternative valuation techniques for predicting UK stock returns, Journal for Asset Management, 5(4):230-250.

FAIRFIELD, P.M. \& HARRIS, T.S. 1993. Price-earnings and price-to-book anomalies: test of an intrinsic value explanation, Contemporary Accounting Research, 9(2):590-611.

FAVERO, C.A. \& PAPI, L. 1995. Technical efficiency and scale efficiency in the Italian Banking Sector: A non-parametric approach, Applied Economics, 27(4):385-395.

FISHER, K.L. \& STATMAN, M. 2002. Blowing bubbles, The Journal of Psycology and Financial Markets, 3(1):53-65.

GIRDZIJAUSKAS, S., ŠTREIMIKIENĖ, D., ČEPINSKIS, J. \& MOSKALIOVA, V. 2009. Formation of economic bubbles: causes and possible preventions, Technological and Economic Development of Economy, 15(2):267-280.

HALKOS, G.E. \& SALAMOURIS, S. 2004. Efficiency measurement of the Greek commercial banks with the use of financial ratios: A data envelopment analysis approach, Management Accounting Research, 15(2): 201-224. 
HALME, M., JORO, T. \& KOIVU, M. 1998. Dealing with interval scale data in data envelopment analysis, International Institute for Applied System Analysis. Available at: http://74.6.239.67/search/cache?ei=UTF$8 \& \mathrm{p}=\mathrm{DEA}+\% 26+$ negative + values $\&$ icp $=1$ [accessed 2009-07-01].

HANKE, E.J., WICHERN, D.W. \& REITSCH, A.G. 2001. Business forecasting (7 $7^{\text {th }}$ ed.) Upper Saddle River, N.J.: Prentice-Hall.

HASSAN AL-TAMIMI, H.A. \& LOOTAH, A.M. 2007. Evaluating the operational and profitability efficiency of a UAE-based commercial bank, Journal of Financial Services Marketing, 11(4):333-348.

HENDERSHOTT, P.H., HENDERSHOTT, R.J. \& WARD, C.R.W. 2003. Corporate equity and commercial property market 'bubbles', Urban Studies, 40(5-6):993-1009.

INVESTOPEDIA. 2009. Warren Buffet: How he does it. Available at: http://www.investopedia.com/articles/ 01/071801.asp [accessed 2009-08-15].

JSE. 2009. Customer relations: Company overview: Market statistics. Available at: http://www.ir.jse.co.za/ phoenix.zhtm/?c=198120 \&p=irol-mktStat [accessed 2009-07-29].

KEYS, D.E., AZAMHUZJAEV, M. \& MACKEY, J. 2001. Economic Value Added ${ }^{(\mathrm{R})}$ : A critical analysis, The Journal of Corporate Accounting and Finance, 73(7):65-71.

LEVINE, D.M., STEPHAN, D.F., KREHBIEL, T.C. \& BERENSON, M.L. 2008. Statistics for managers using Microsoft Excel. ( $5^{\text {th }}$ ed.) New Jersey: Pearson.

LUO, X. 2003. Evaluating the profitability and marketability efficiency of large banks: An application of data envelopment analysis, Journal of Business Research, 56:627-635.

MELAS, D. \& RUBAN, O. 2009. Die opstelling van modelle van finansiële tydreekse, Beleggingsinsigte (Bylaag in Fin Week), 23 Jul, 18:22.

MILLARD, S.P. \& NEERCHAL, H.K. 2001. Environmental statistics with S-plus, Boa Raton, Florida: CRC Press.

NEL, I. 2005. Financial management: Study guide for MDTP 822, Potchefstroom: North-West University. OBERHOLZER, M. \& VAN DER WESTHUIZEN, G. 2004. An empirical study on measuring profitability and efficiency of bank regions, Meditari Accounting Research, 12(1):165-178.

OBERHOLZER, M. \& VAN DER WESTHUIZEN, G. 2009. Estimating technical and scale efficiency in banks and its relationship with economic value added: A South African study, South African Journal of Accounting Research, 23(1):67-86.

ORLITZKY, M., SCHMIDT, F.L. \& RYNES, S.L. 2003. Corporate social and financial performance: a meta-analysis, Organization Studies, 24(3):403-441.

PARK, Y.S. \& LEE, J-J. 2003. An empirical study on the relevance of applying relative valuation models to investment strategies in Japanese stock market, Japan and the World Economy, 15(3):331-340.

PAULSEN, J. 2008. Optimal dividend payment and reinvestment of diffusion process with both fixed and proportional costs, Society for Industrial and Applied Mathematics, 47(5):2201-2226.

POSEN, A.S. 2006. Why central banks should not burst bubbles, International Finance, 9(1):109-124.

RAMCHARRAN, H. 2003. Estimating the impact of risk on emerging equity market performance: further evidence on data from rating agencies, The Multinational Business Review, 11(3):77-89.

RAMCHARRAN, H. \& KIM, D. 2008. Estimating the dynamic impact of financial liberalization on equity returns in Southeast Asian markets, The Multinational Business Review, 16(3):101:118.

RAPPAPORT, A. 1986. Creating shareholders value: The new standard for business performance, New York: Free Press.

RAY. S.C. 2004. Data envelopment analysis: Theory and techniques for economics and operational research, Cambridge: Cambridge University Press.

SANFORD, J. 2005. Caution advised, Canadian Business, 78(2):45-46.

SCHROEDER, A. 2008. The snowball: Warren Buffet and the business of life, London: Bloomsbury Publishing.

SEINFORD, L.M. \& ZHU, J. 1999. Profitability and marketability of the top 55 US commercial banks, Management Science, 45(9): 1270-1288.

SEKARAN, U. 2006. Research methods for business: A skill building approach $\left(4^{\text {th }}\right.$ ed.) Singapore: Wiley. 
STAVAREK, D. 2002. Comparison of the relative efficiency of banks in European transition economies, Proceedings of the D.A. Tsenov Academy of Economics $50^{\text {th }}$ Anniversary Financial Conference, Svishtov, Bulgaria:955-971.

STEWART, G.B. 1999. The quest for value, New York: Harper Business.

THOMAS, D. \& TRIPE, D. 2007. An investigation into the efficiency of a bank's branch network using data envelopment analysis. Available at: http://www.mel bournecentre.com.au/Finsia_MCFC/2007/DavidTripe_1 [accessed 2009-06-12].

VOSE, D. 1996. Quantitative risk analysis: A guide to Monte Carlo simulation modelling, Chichester: Wiley. WEGNER, T. 2007. Applied business statistics: Methods and Excel-based applications ( ${ }^{\text {nd }}$ ed.) Cape Town: Juta.

YEH, Q. 1996. The application of Data Envelopment Analysis in conjunction with financial ratios for bank performance evaluation, Journal of the Operational Research Society, 47:980-988.

ZHU, J. 2004. Quantitative models for performance evaluation and benchmarking: Data envelopment with spreadsheets and DEA Excel Solver, Norwell, Massachusetts: Kluwer. 